\title{
КЛАСИФИКАЦИЈСКЕ БОРБЕ
}

Pierre Bourdieu (2018) Classification Struggles: General Sociology, Volume I. Lectures at the College de France, 1981-82. Cambridge: Polity Press.

Књигом Класификаиијске борбе, издавачка кућа Polity 2018. године отпочиње петотомну едицију која читаоцима нуди драгоцени увид у предавања на курсу Опште социологије на Колеж де Франсу (Collège de France), у оквиру ког је чувени француски социолог Пјер Бурдије (Pierre Bourdieu) од 1982. до 1986. године студентима, истраживачима и заинтересованој јавности излагао основе свог социолошког приступа. Други том, посвећен појмовима хабитус и поље, изашао је 2019. године.

У предавањима објављеним у овој књизи, Бурдије настоји да прецизно утврди односе између класификација које производе научници у природним и друштвеним наукама, друштвених услова у којима се те класификације производе и класификација које дејственици (друштвени актери) стварају у свакодневном животу. Ово је посебно важно јер социологија као наука проучава субјекте који и сами класификују од тренутка када постају друштвени субјекти јер је само тако, према Бурдијеовом мишљењу, друштвени свет могућ. Дејственици су именоване (номиноване) индивидуе, одређене и конституисане „именом“" које чини да постану оно што јесу (стр. 11). Ово није само језички чин, именовање и класификовање су фундаментални друштвени процеси, процедуре којима дејственици класификују свет око себе и - у складу са Бурдијеовом општом теоријском поставком - уједно представљају извориште симболичке доминације и предмет су сукоба. Бурдије све класификације, како у науци тако и у друштву, види и као циљ и као оружје у симболичким борбама, а сукоби око класификација за њега представљају и занемарену димензију класне борбе. Улог у таквој борби је симболичка моћ која омогућава монопол над дефиницијом легитимних принципа хијерархизације у друштву и производи натура-


поделе и визије једнако битни у овој игри речима.

Један од примера класификацијских борби на који се Бурдије често враћа током својих предавања су увреде (јавне оптужбе), које указују на битну карактеристику процеса класификовања у свакодневном животу. Увреда је вид

\footnotetext{
${ }^{1}$ tamara.petrovic@f.bg.ac.rs
} 
симболичке борбе, друштвено ризични чин који излаже особу која је изриче спољном просуђивању, доводи је у рањиво стање у ком говорник мора да „гарантује“ за оно што је изречено. Овим Бурдије уводи у причу и важну димензију процеса класификације - друштвени статус говорника. Пошто је све не само језичко, већ и друштвено - није важно само како је нешто изречено и тим чином категоризовано, већ су друштвени услови производње класификације и конкретно друштвени статус, ауторитет и „легитимност“ говорника оно што говорнику даје примат или отежавајућу околност у симболичкој борби. Класификације чине друштвени свет могућим, али оне се не догађају у вакууму, и социолози не смеју да забораве да приступајући анализи класификација у друштвеном животу, у обзир узму и фундаменталан проблем ауторитета класификатора, другим речима, да изнесу на видело и који су то дејственици (или друштвена група којој припадају) у важећем друштвеном поретку „квалификовани“ и „,ауторизовани“ да класификују. Бурдије се овде осврће и на Дистинкųujy, јер суд о укусу увек представља нечији суд о нечијем укусу (најчешће о неукусу, примећује сам аутор) и произведен је у тачно одређеним друштвеним условима. У књизи се налазе и други примери сукоба око класификација и анализе стратегија само-представљања различитих појединаца и група. Такође, Бурдије у предавањима говори и о чиновима институисања, конституисања, представљања и делегирања, све време имајући на уму како друштвене услове у којима настају, тако и улогу и моћ језика у тим процесима.

Нису само „обични“ друштвени актери и њихове класификације предмет Бурдијеових предавања објављених у овој књизи. Једнако важно, ако не и важније, место у поглављима Класификацијских борби, добија статус социолошког дискурса о друштвеном свету. Бурдије поставља питање да ли је социолог ближи особи која својим језичким и друштвеним чином вређа другу особу и тако је класификује или, с друге стране, ботаничару, свом колеги из природних наука (стр. 22). Да ли социолошки рад може бити протумачен и као увреда? Овде је реч о дистинкцији између констатива и перформатива (Остин) и Бурдије се пита колико социолози у свом раду могу успети да се задрже на констативном полу дистинкције, када је предмет њиховог проучавања - друштвени свет - универзум саткан од једног перформатива за другим, а симболичка моћ (наметање, застрашивање, „симболички блеф“) лежи чак и у привидно безазленим исказима који се поимају као констативи. Шта у том смислу социлог чини када својим ауторитетом установи и јавности саопшти да „постоје две друштвене класе““ (стр. 23)?

У различитим сабраним предавањима, Бурдије даје и конкретне савете социолозима и истраживачима: чиме да се воде када осмишљавају упитник, како да прикупе што више релевантних података о друштвеној стварности коју испитују са што мање питања, који су критеријуми за добар индикатор, како да класификују добијену грађу, како да буду свесни одређених облика пристрасности које уносе у истраживачки поступак својом теоријском поставком и позицијом у друштву, итд. Више од конкретних савета, Бурдије указује на важност начина размишљања и начина постављања питања у социологији, 
јер сама природа социолошке праксе чини да методолошка и епистемолошка питања буду нужно увезана са политичким. „Чак и када тога нисмо свесни“, наводи он, „увек се бавимо политиком када се бавимо социологијом“ (стр. 30).

Начин на који људи у свакодневном животу тумаче стварност за Бурдијеа представља неизоставан део те стварности. Зато изнова упозорава социологе да је важно да буду свесни да у свакој ситуацији када долазе у контакт са испитаницима постају и класификатори класификујућих субјеката. Добро познат и кључан елемент Бурдијеове социологије јесте интеграција објективистичког приступа и праксеолошке перспективе актера, најпре раскидом са претходно постојећим класификацијама у свакодневном животу, а затим и њиховом накнадном интеграцијом у новостворени корпус социолошког знања. Однос између субјективног и објективног аспекта у друштвеним наукама важна је тема ове књиге.

У типично „бурдијеовској“ опаски, овај социолог на једном месту истиче како су комичари савезници социолога, јер теже да поставе она питања која нас наше свакодневне рутине терају да заборављамо (стр. 10). Бурдије је, заиста, увек истраживао и доводио у питање „скривену страну друштвеног света“ (стр. 50), све оно што што докса „скрива“ иза „саморазумљивог“ и „природног“ у свакодневном животу и позивао социологе да „чепркајући“" по пукотинама у симболичком поретку, раз-откривају симболичку моћ и неједнакости у самим темељима друштвене стварности. За социологију се онда може рећи да је инхерентно критичка научна дисциплина, чак и у најширем смислу, када у потрази за објективним индикаторима, социолози из латентног, практичког стања на површину износе и оне информације које испитаници свесно или несвесно не (желе да) поделе са њима. Управо та интеракција између испитаника који несвесно о себи открива важан емпиријски податак и социолога који то бележи може да изроди научну истину (стр. 36), која онда заузврат дејственицима може да понуди увиде којима ће на нови и другачији начин рефлектовати (осветлити) и тумачити свет око себе и сопствену позицију у том свету. Однос између научног и свакодневног (,лаичког“), као и испреплетаност епистемолошке и политичке димензије били су готово стални предмет Бурдијеовог проучавања, стога није необично да чине и окосницу Класификащијских борби.

Први том Бурдијеове Опште социологије, испричане кроз призму социологије друштвених класификација, представља добар подстицај новим генерацијама социолога, као и њихових колега из сродних поља проучавања (антропологије, политичких наука, примењене лингвистике и студија дискурса и др.) да ближе упознају Бурдијеову визију социологије као науке о скривеној страни друштвеног света. Како је реч о транскриптима предавања, ово је уједно и прилика да се то учини на приступачан начин, сажето, али уз бројне примере и повремене занимљиве дигресије, уз константно прецизан стил излагања. Иако су у току претходне две деценије поједина предавања овог француског социолога (о науци, држави и уметности) објављивана у преводу на енглески језик, едиција из опште социологије би требало да нађе место у социолошким силабусима. Прва књига ће свакако бити корисна и оним социолозима који већ 
добро познају Бурдијеа, али су прижељкивали да се на једном месту нађе оно што су до сада о класификацијама и класификацијским борбама слагали из сегмената раштрканих у различитим делима овог аутора. А није мало таквих ни у домаћој, ни у регионалној социолошкој заједници. 